Volume 3 Issue 7 (March 2021) PP. 111-119

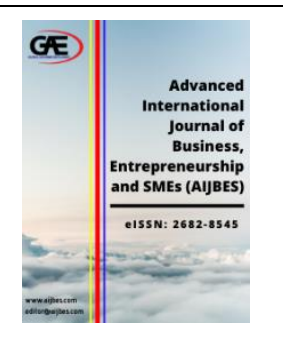

\author{
ADVANCED INTERNATIONAL JOURNAL OF \\ BUSINESS, ENTREPRENEURSHIP AND SMES \\ (AIJBES) \\ www.aijbes.com
}

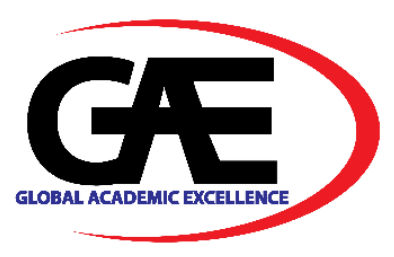

\title{
CONSUMER PREFERENCES AND PRICING MODEL ON BUBBLE TEA PURCHASE IN BANDUNG, INDONESIA
}

\author{
Candice Iswara $^{1 *}$, Raden Aswin Rahadi ${ }^{2}$ \\ $1 \quad$ School of Business and Management, Institut Teknologi Bandung \\ Email: candice_iswara@sbm-itb.ac.id \\ 2 School of Business and Management, Institut Teknologi Bandung \\ Email: aswin.rahadi@sbm-itb.ac.id \\ * Corresponding Author
}

Article Info:
Article history:
Received date:28.02.2021
Revised date: 03.03 .2021
Accepted date: 21.03 .2021
Published date: 31.03 .2021
To cite this document:
Iswara, C., \& Rahadi, R. A. (2021).
Consumer Preferences and Pricing
Model on Bubble Tea Purchase in
Bandung, Indonesia. Advanced
International Journal of Business,
Entrepreneurship and SMEs, 3 (7),
111-119.

DOI: 10.35631/AIJBES.37009.

This work is licensed under CC BY 4.0

\begin{abstract}
:
Bubble tea currently represents a popular drink among Generation $\mathrm{Z}$ in Indonesia. Their quality varies according to intrinsic and extrinsic aspects that can sometimes be modified to make it more desirable. As consumers are the final economic activity actor in the production chain, it is beneficial to identify which factors affect their behavioural patterns. This fact would allow the bubble tea shop owners to satisfy better consumer expectations, demands, and needs. This paper focuses on features that might influence consumer behaviour, preferences, and perception of bubble tea beverage and determine any differences in bubble tea purchasing power. The research will use a quantitative approach by distributing questionnaires to Generation $\mathrm{Z}$ and analyzing several aspects: price, taste, product design, brand influence, and location accessibility.
\end{abstract}

Keywords:

Consumer Preferences, Willingness to Pay, Brand, Bubble Tea, Indonesia

\section{Introduction}

In this era, due to the developing business, people are competing intensely with one another to produce the best goods and attract customers by using various strategies and methods. The same phenomenon is also currently happening in Indonesia, especially in the culinary sector due to its high demand. The culinary sector has the most significant contribution to make in the creative industry in Indonesia. In 2018, Indonesia's revenue in food and beverages markets amounted to IDR 3.6 trillion or USD 253 million (International, 2020). According to Grab's results, in 2018, the demand for bubble tea in the Southeast Asia region increased at a rate of Copyright $\odot$ GLOBAL ACADEMIC EXCELLENCE (M) SDN BHD - All rights reserved 
Volume 3 Issue 7 (March 2021) PP. 111-119 DOI 10.35631/AIJBES.37009

3,000 per cent. Currently, GrabFood has approximately 4,000 bubble tea outlets in their network due to rising customer demand, which also happens to be a 200 percent increase in outlets for the region. Grab also found that Southeast Asians drink four cups of bubble tea per person per month on average. Three cups a month per person is consumed by Malaysia, Singapore, Vietnam, and Indonesia (Team, 2019). Bubble tea is quite popular among Indonesians because this product is easy to find in any city. The positive response of the people in Indonesia to the bubble tea led to the emergence of many new brands of the same type and made bubble tea competition even tougher (Hakim et al., 2020).

Bubble tea is a cold tea-based beverage from Taiwan usually infused with flavourings and milk. The mixture is shaken vigorously in a cocktail shaker to produce "bubbles". Additional topping known as pearl jelly (black tapioca balls) that look like "bubbles" is subsequently added to the drink. The term "bubble" refers not just to the bubbles formed on top of the drink but also to the bottom's black tapioca balls (Teo \& Khoh, 2015).

In 2015, the ministry of tourism and creative economy determined Bali, Yogyakarta, Bandung, Solo, and Semarang as five major gastronomic destinations in Indonesia (Kristanti et al., 2019). Bandung is one of the cities in Indonesia, which is famous for its cuisine. The bubble tea phenomenon is currently widespread in Bandung, causing many bubble teas shops to emerge. However, there are several brands whose names are quite large and well known in Bandung.

Visiting a bubble tea shop is a popular leisure activity among Generation Z, according to a survey by market research firm Nielsen (Nguyen, 2019). The survey of 210 Generation Z people in Hanoi and Ho Chi Minh City last October found 81 percent of respondents saying bubble tea shops were their favourite hangouts. Although bubble tea is also popular among Millenials, most Millennials drink coffee. Meanwhile, Generation Z, especially those in their teens, do not drink coffee, but they will gladly pay for a cup of bubble tea. Teenagers are a large customer group for tea-based drinks, hence the high demand for bubble tea (Nguyen, 2019).

One crucial aspect that needs to be considered to succeed in the culinary industry is the customer preferences that determine and influence consumers' judgment in understanding the value of a product. Preference is essential because it represents the way the buyer views the product or service. To influence the consumers, it is necessary to understand the consumer's perception of a product, so the product is recognized, interpreted, and stored in their memory for consumer perception fundamentals (Durmaz, 2014). By identifying the changes in the consumer behaviour, the businesses can modify their offering to the consumers. (Bhatia \& Jain, 2014).

Consumers' preferences for products arise from the combination of different factors. Some factors come from features of the product (e.g., price, design). In contrast, others are attributes of consumers (e.g., their goals, attitudes, income), (Gautama \& Rahadi, 2020). Each brand offers a different choice of taste, price, product design. With so many factors that influence consumer perceptions in choosing a bubble tea shop, everyone will have different perceptions regarding bubble tea selection. Consumers' value attributes are used to evaluate a product concerning the benefits consumers seek when purchasing such a product. Consumers also use attributes to make comparisons between competitive brands (Akpoyomare et al., 2013). 
Volume 3 Issue 7 (March 2021) PP. 111-119 DOI 10.35631/AIJBES.37009

This research aims to determine the consumer preferences in choosing bubble tea shops in Bandung city, Indonesia. By identifying consumer preferences, it will help bubble tea shop owners and future owners to understand and determine the right strategies in attracting consumers to grow their business in the industry.

\section{Literature Review}

\section{Consumer Preferences}

Consumers' preferences for products or brands arise from the combination of different factors. Some factors come from features of the product (e.g., price, design). In contrast, others are attributes of consumers (e.g., their goals, attitudes, discretionary income), (Gautama \& Rahadi, 2020). The consumer preferences have a significant influence on consumer behaviour. Consumers use such cues as product quality, corporate image and name recognition, and price to differentiate alternatives and form impressions of product and service quality (Pavesic, 1989). According to (Kochina, 2019), how customers choose their products and services can be extremely important as a competitive advantage over their competitors in many ways. By analyzing consumer preferences, sellers can identify the importance of product attributes (Salomon et al., 2020).

\section{Price}

Price is defined as the amount of money charged when a consumer buys a good / service. Price is the value that consumers exchange to enjoy a product/service (Pattarakitham, 2015). According to (Delon et al., 2010), there is a positive relationship between perceived price fairness and satisfaction, ultimately affecting the customer's overall satisfaction. Font-i-Furnols \& Guerrero (2014) also stated. However, the price seems not to be the most important attribute when purchasing, usually lower prices are preferred and are probably important for a consumer with low purchasing power. Consumer and price are closely related. A person's economic condition affects decision-making behaviour in purchasing a product or service.

\section{Taste}

Taste determines the flavours and recipes used to prepare a specific product to influence consumers to buy continuously. Taste and smell are the body's principal mechanism for assessing foods' chemical composition for both nutrients and toxicity (Morini, 2007). Many factors affect consumers' acceptability of foods. Taste and other sensory characteristics occupy a crucial position. However, taste must be faultless since it strongly influences food choices (Lyly et al., 2007).

\section{Product Design}

According to (Issue, 2015), packaging has four distinct marketing functions. It contains and protects the product, promotes the product, helps consumers use the product and facilitates recycling and reduces environmental damage. Therefore, packaging does more than just protecting the company's products. It also helps in developing the image of the product in the consumer mind. So, ignoring the packaging design can decrease the chances of being visible and attractive, resulting in using sales.

\section{Brand Influence}

Brand image referred to as the consumer perception regarding a brand (Pattarakitham, 2015). Suppose consumers can recognize and remember a brand that is part of a group in a particular product. In that case, it can be concluded that the person is aware of a brand (Tee et al., 2020). 
Volume 3 Issue 7 (March 2021) PP. 111-119 DOI 10.35631/AIJBES.37009

In creating loyal consumers, companies must be able to improve the brand image of their products. Without a healthy and positive brand image, it is challenging for companies to attract new customers and retain existing ones (Kharisma et al., 2017).

\section{Location Accessibility}

Location accessibility is a measurement of the comfort and ease in achieving a location and its relationship with each other, easy or difficult. The location is achieved through transportation (Hakim et al., 2020). Location selection is one of the most critical factors to the success of long-term strategic decisions taken in the restaurant industry. A suitable restaurant location can attract more customers, provide convenient service to customers, and enhance customer loyalty (Chen \& Tsai, 2016). Wang, Tran, and Nguyen (2014) found that the restaurant's location positively affects brand loyalty, and it is considered a dimension of brand equity.

\section{Willingness to Pay}

Willingness to pay is referred to as a measurement of purchase intention considered actual behaviour (De Pelsmacker et al., 2005). Repurchase interest is a consumer willingness to pay for the same product previously purchased by weighing the situation, consumer preferences, and product performance with consumer expectations (Hakim et al., 2020).

\section{Generation Z}

A study by Simangunsong (2018) divides generations of consumers into four categories, i.e., baby boomers, Generation-X, Generation-Y, and Generation-Z. According to Resti \& Putri (2018), the generation born after Generation Y or Millennial (1981-1995) is Generation Z or Post-Millennial (1995-2010). Generations in a world with web, internet, smartphones, laptops, freely available networks, and digital media are considered the Generation Z (Singh \& Dangmei, 2016).

\section{Gastronomic Condition in Indonesia}

Gastronomic tourism is one main factor that influences a person to visit a specific destination (Octaviany \& Ervina, 2017). According to the Ministry of Industry, an increase in Indonesia's food and beverage industry has occurred in the first quarter of 2018 by $12.70 \%$ and in the $8.41 \%$ increase in the beverage industry (Hakim et al., 2020). The F \& B industry also plays an essential role in exporting products by USD 456.6 million and absorbing a workforce of more than 4 million people.

In 2015, the Ministry of Tourism and Creative Economy designated five major gastronomic destinations in Indonesia. They are Bali, Yogyakarta, Bandung, Solo and Semarang (Kristanti et al., 2018). In 2019, many new food and beverages innovations were emerging in Indonesia, one of which is bubble tea beverage products (Ransulangi et al., 2017). This result also applies to the city of Bandung.

\section{Price towards Consumer Willingness to Pay}

Buyers are conscious of the prices they pay, influence the role price plays in buyers' choice process, and that buyers consider past prices as a basis for a product's fair price. The willingness to pay would be related to a consumer's perception of fair price and willingness to pay based on the consumer's perceptions of the prices that he or she has observed for a brand (Krishna, 1991). Studies have shown that minor variations of prices and the corresponding consumer behaviour can have notable effects on revenues and profits (Gautama \& Rahadi, 2020). 


\section{Taste towards Consumer Willingness to Pay}

The perception of the product, such as flavour/taste, does have a well-documented effect on consumers' willingness to pay (Sörqvist et al., 2013). Font-i-Furnols \& Guerrero (2014) also stated that taste is positively correlated with the overall experienced quality, intention to purchase and willingness to pay.

\section{Product Design towards Consumer Willingness to Pay}

Product packaging or product design may influence gustatory perception, evaluations, and, in turn, the desire for the food and beverages as well as willingness to pay (Kampfer et al., 2017).

\section{Brand Influence on Consumer Willingness to Pay}

If the consumer is less aware of the high deal frequency for a brand, they may not try to purchase the brand only on deal and consequently would be willing to pay a higher price for the brand. Hence, the dealing pattern may affect the consumer's perceived deal frequency for a brand and, consequently, influence consumers' willingness to pay for the brand. If consumers are willing to pay more for a brand, the manager could get a higher price for it and make more enormous profits (Krishna, 1991).

\section{Location Accessibility towards Consumer Willingness to Pay}

Restaurants can gain relative advantage if they provide consumers with convenient locations. The choice of location is a crucial factor that can affect a restaurant's success or failure. A good location considers the geographic, demographic, and psychographic factors, and any changes in these factors could have a significant influence on the consumers' willingness to pay (Hanaysha, 2016).

\section{Methodology}

The first step conducted by the researcher is to determine the topic which is Consumer Preferences and Pricing Model On Bubble Tea Purchase in Bandung, Indonesia. Then, the researcher identifies the problem and conducts a preliminary research. The preliminary study conducted to determine some information related to the selected problem. Preliminary study was conducted on Sunday, October 4th 2020, involving 15 respondents. The respondents were limited to people who are regular customers of bubble tea, domiciled in Bandung, Indonesia and born between 1995-2010. The data was collected using judgmental sampling with a nonsequential approach. This preliminary study is conducted to determine the 4 top popular bubble tea brands in Bandung, Indonesia, therefore the author can narrow the scope of the research. Based on the preliminary study, the four chosen brands become brands that will be used to be analyzed.

After conducting the preliminary study, the researcher also determines the research questions, research objectives, research scope and limitations related to the topic. The researcher also collects data in the form of primary and secondary data. This research collects primary data by distributing a questionnaire. The questionnaire targeted Generation Z (born between 19952010) domiciled in Bandung. The questionnaire gathered will represent the respondents' preferences and price limits in buying bubble tea. The researcher needs to distribute 400 valid questionnaires after conducting a validation and reliability test with a total of 40 respondents, $10 \%$ of the total sample size. To enrich researcher's information to support the research, the researcher collects data from secondary resources, such as journals, research publications, textbooks and official websites that have relevance to the research topic, with a total of 43 
Volume 3 Issue 7 (March 2021) PP. 111-119 DOI 10.35631/AIJBES.37009

papers, as the secondary data. In this study, the researcher will use a statistical approach. To conduct the validation and reliability test, the researcher will use Pearson Correlation using confidence level of $95 \%$. The statistical test used will be Kruskal Wallis Non-Parametric test with $95 \%$ confidence level to test the respondents' influence and purchasing power on purchasing bubble tea for several chosen brands. The researcher will also use one-way ANOVA to test the significance of bubble tea shop's distance, location, and accessibility that will be correlated with the activities area of the respondents.

\section{Discussion and Analysis}

Based on the discussion, this study can conclude that there are five indicators that consumers must consider before purchasing a bubble tea product. The key factors are price, taste, product design, brand influence and location accessibility. This research's findings can be used to determine marketing strategies, product strategies, and pricing strategies for bubble tea shop owners. For this study, the conceptual framework, as depicted in figure 2.1.

In this section, the author identifies and classifies different factors that influence consumers to purchase bubble tea among Generation Z. Below is the proposed conceptual framework that can describe factors that influence consumers on purchasing bubble tea.

\section{Source: Author's Interpretation}

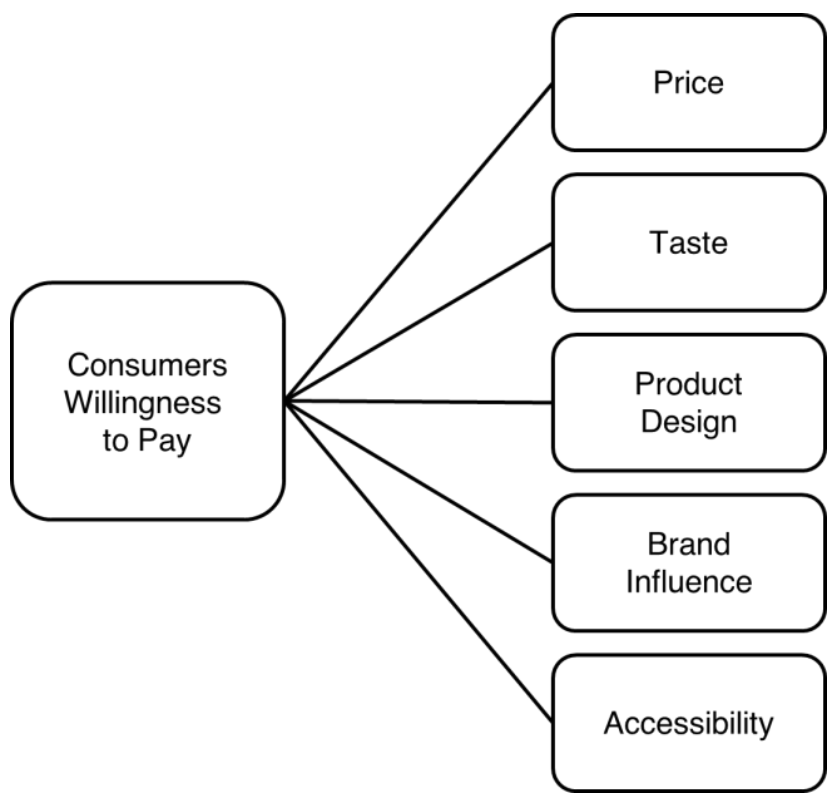

Figure 1. Conceptual Framework

As we can see from the figure, the consumer willingness to pay and purchase bubble tea is influenced by five factors: Price, taste, product design, brand influence and location accessibility. Other than that, there are many more factors that might influence consumers to purchase bubble tea. However, in this research, the author will be focusing on the five key factors. Consumers' preferences for products arise from the combination of different factors. Some factors come from features of the product (e.g., price, design). The independent variables from the conceptual framework are price, taste, product design, brand influence and accessibility. On the other hand, the dependent variable is consumer willingness to pay on purchasing bubble tea. 
Volume 3 Issue 7 (March 2021) PP. 111-119 DOI 10.35631/AIJBES.37009

In contrast, others are attributes of consumers (e.g., their goals, attitudes, income), (Gautama $\&$ Rahadi, 2020). Each brand offers a different choice of taste, price, product design. With so many factors that influence consumer perceptions in choosing a bubble tea shop, everyone will have different perceptions regarding bubble tea selection. Consumers' value attributes are used to evaluate a product concerning the benefits consumers seek when purchasing such a product. Consumers also use attributes to make comparisons between competitive brands (Akpoyomare et al., 2013). Repurchase interest is a consumer willingness to pay for the same product previously purchased by weighing the situation, consumer preferences, and product performance with consumer expectations (Hakim et al., 2020). By analyzing the consumer preferences on purchasing bubble tea, the author wants to help the bubble tea owners to gain the "repurchase interest" from their customers.

\section{Conclusions}

This research shows the respondent's response to some factors relating to consumer preferences in purchasing bubble tea. Some of the different aspects that influence consumers are price, taste, product design, brand influence and location accessibility. This research in the proposed conceptual model will be used and tested in the future study. The conceptual model will be checked using quantitative methods by distributing questionnaires and analyzed with statistical tests. This research will help bubble tea shop owners and future owners address the right target market and figure out consumer preferences to grow their business, as the business of bubble tea beverage is currently emerging in Indonesia. For a better understanding of the consumer preferences of bubble tea purchases in Bandung, Indonesia, another study related to bubble tea and beverages preferences could be compared with this research's findings.

\section{References}

Akpoyomare, O. Ben, Adeosun, L. P. K., \& Ganiyu, R. A. (2013). The Influence of Product Attributes on Consumer Purchase Decision in the Nigerian Food and Beverages Industry: A Study of Lagos Metropolis. American Journal of Business and Management, 2(1), 196. https://doi.org/10.11634/216796061706211

Bhatia, M., \& Jain, A. (2014). Green Marketing: A Study of Consumer Perception and Preferences in India. Electronic Green Journal, 1(36). https://doi.org/10.5070/g313618392

Chen, L. F., \& Tsai, C. T. (2016). Data mining framework based on rough set theory to improve location selection decisions: A restaurant chain case study. Tourism Management, 53, 197-206. https://doi.org/10.1016/j.tourman.2015.10.001

Delon, G., Terwagne, D., Adami, N., Bronfort, A., Vandewalle, N., Dorbolo, S., \& Caps, H. (2010). Faraday instability on a network. Chaos, 20(4), 284-300. https://doi.org/10.1063/1.3518693

De Pelsmacker, P., Driesen, L., \& Rayp, G. (2005). Do consumers Care about ethics? Willingness to pay for fair-trade coffee. Journal of Consumer Affairs, 39(2), 363-385. https://doi.org/10.1111/j.1745-6606.2005.00019.x

Durmaz, Y. (2014). a Theoretical Approach To the Role of Perception on the. September 2011, 2-7.

Font-i-Furnols, M., \& Guerrero, L. (2014). Consumer preference, behavior and perception about meat and meat products: An overview. Meat Science, 98(3), 361-371. https://doi.org/10.1016/j.meatsci.2014.06.025

Gautama, A., \& Rahardi, A. (2020). Coffee Shops Consumptions Preferences Model in Jakarta. Ajibes, 1(1), 100-2000. 
Volume 3 Issue 7 (March 2021) PP. 111-119 DOI 10.35631/AIJBES.37009

Hakim, N., Suwandari, L., \& Nawarini, A. T. (2020). The Influence of Quality Perception, Price Fairness, Brand Experience, and Accessibility to Repurchase Interest ( Study on Consumer Chatime in Purwokerto ). 22(1), 28-38.

Hanaysha, J. (2016). Restaurant Location and Price Fairness as Key Determinants of Brand Equity: A Study on Fast Food Restaurant Industry. Business and Economic Research, 6(1), 310. https://doi.org/10.5296/ber.v6i1.9352

International, P. (2020, August 03). Food and Beverages Sector in Indonesia. Retrieved October 08, 2020, from https://www.cekindo.com/sectors/food-beverages

Issue, $\mathrm{S}$. (2015). 189-875-1-Pb. 4(1), 232-240

Kampfer, K., Leischnig, A., Ivens, B. S., \& Spence, C. (2017). Touch-flavor transference: Assessing the effect of packaging weight on gustatory evaluations, desire for food and beverages, and willingness to pay. PLoS ONE, 12(10), 1-17. https://doi.org/10.1371/journal.pone.0186121

Kharisma, S., Arifin, Z., \& Wilopo, W. (2017). PENGARUH INTERNATIONAL BRAND IMAGE DAN KUALITAS PRODUK TERHADAP KEPUTUSAN PEMBELIAN (Survei pada pemilik smartphone Lenovo di Kawasan Asia Tenggara). Jurnal Administrasi Bisnis S1 Universitas Brawijaya, 50(1), 91-97.

Kochina, K. (2019). A Study of Consumer Buying Behaviour and Consumers' Attitude on Sustainable Production and Consumption in the Food and Beverage Sector // Estudio del comportamiento de Compra y la actitud del consumidor hacia la producción y consumo sustentables en el sec. 1-56.

Kristanti, M., Jokom, R., \& Widjaja, D. C. (2019). Culinary Experience of Domestic Tourists in Indonesia: A Study on Denpasar and Yogyakarta Tourist Destinations. 69(Teams 2018), 132-135. https://doi.org/10.2991/teams-18.2019.23

Krishna, A. (1991). Effect of Dealing Patterns on Consumer Perceptions of Deal Frequency and Willingness to Pay. Journal of Marketing Research, 28(4), 441. https://doi.org/10.2307/3172784

Lyly, M., Roininen, K., Honkapää, K., Poutanen, K., \& Lähteenmäki, L. (2007). Factors influencing consumers' willingness to use beverages and ready-to-eat frozen soups containing oat $\beta$-glucan in Finland, France and Sweden. Food Quality and Preference, 18(2), 242-255. https://doi.org/10.1016/j.foodqual.2005.12.001

Morini, G. (2007). "Molecular Aspects of Taste." Gastronomic Sciences, London. Morris, R. (2009). "The fundamentals of product design.” AVA Publishing. ISBN 2- 940373-175.

Nguyen, D. (2019, February 01). Generation Z motivates Vietnamese entrepreneurs to open bubble tea shops - VnExpress International. Retrieved December 13, 2020, from https://e.vnexpress.net/news/business/economy/generation-z-motivates-vietnameseentrepreneurs-to-open-bubble-tea-shops-3872358.html

Octaviany, V., \& Ervina, E. (2017). the Creation of Visitor Satisfaction Through Quality of Experience in the Gastronomic Tourism At the City of Bandung, Indonesia. Journal of Business on Hospitality and Tourism, 2(1), 44. https://doi.org/10.22334/jbhost.v2i1.40

Pattarakitham, A. (2015). The Factors Influence Customer Satisfaction and Loyalty: A Study of Tea Beverage in Bangkok. SSRN Electronic Journal. https://doi.org/10.2139/ssrn.2593883

Pavesic, D. V. (1989). Psychological aspects of menu pricing. International Journal of Hospitality Management, 8(1), 43-49. https://doi.org/10.1016/0278-4319(89)90030-3

Ransulangi, G. S. T., Waney, N. F. L., \& Dumais, J. N. K. (2017). Pengaruh Komponen Citra Merek (Brand Image) Terhadap Loyalitas Konsumen Produk Minuman Share Tea Di 
Volume 3 Issue 7 (March 2021) PP. 111-119
Kota
Manado.
Agri-Sosioekonomi,
$13(2)$,
79.

DOI 10.35631/AIJBES.37009 https://doi.org/10.35791/agrsosek.13.2.2017.16380

Resti, N., \& Putri, R. (2018). Factors Influencing Electronic Payment Instrument Usage to Support Cashless Society among Generation $Z$ in Bandung City By

Salomon, L. L., Kosasih, W., Doaly, C. O., \& Cindy. (2020). Consumer preference analysis of snack using conjoint analysis method (case study: Telurgabus). IOP Conference Series: Materials Science and Engineering, 852(1). https://doi.org/10.1088/1757$899 X / 852 / 1 / 012120$

Simangunsong, E. (2018). Generation-Z Buying Behaviour in Indonesia: Opportunities for Retail Businesses. Mix: Jurnal Ilmiah Manajemen, 8(2), 243. https://doi.org/10.22441/mix.2018.v8i2.004

Singh, A. P., \& Dangmei, J. (2016). Understanding the Generation Z: the Future Workforce. South -Asian Journal of Multidisciplinary Studies, April.

Sörqvist, P., Hedblom, D., Holmgren, M., Haga, A., Langeborg, L., Nöstl, A., \& Kågström, J. (2013). Who needs cream and sugar when there is eco-labeling? Taste and willingness to pay for "eco-friendly" coffee. PLoS ONE, 8(12). https://doi.org/10.1371/journal.pone.0080719

Team, T. (2019, December 27). Southeast Asia's bubble tea craze. Retrieved October 05, 2020, from https://theaseanpost.com/article/southeast-asias-bubble-tea-craze

Tee, J., Erdiansyah, R., \& Aulia, S. (2020). Pengaruh Word Of Mouth dan Brand Awareness terhadap Keputusan Pembelian Xing Fu Tang di Indonesia. Prologia, 4(1), 18. https://doi.org/10.24912/pr.v4i1.6420

Teo, T. W., \& Khoh, R. L. (2015). Teaching science in culturally relevant ways: Ideas from Singapore teachers. Singapore: World Scientific.

Wang, L. W., Tran, T. T., \& Nguyen, N. T. (2014). “Analyzing factors to improve service quality of local specialties restaurants: A Comparison with fast-food restaurants in Southern Vietnam.” Asian Economic and Financial Review, 4(11), 1592-1606. 